\title{
Standardization of growing media for hardening plantlets of Dendrobium var. Thongchai Gold
}

\section{VS Sabareeswaran, R Swarnapriya \& M Kannan}

Journal of Agriculture and Ecology

ISSN: 2456-9410

Volume: 6

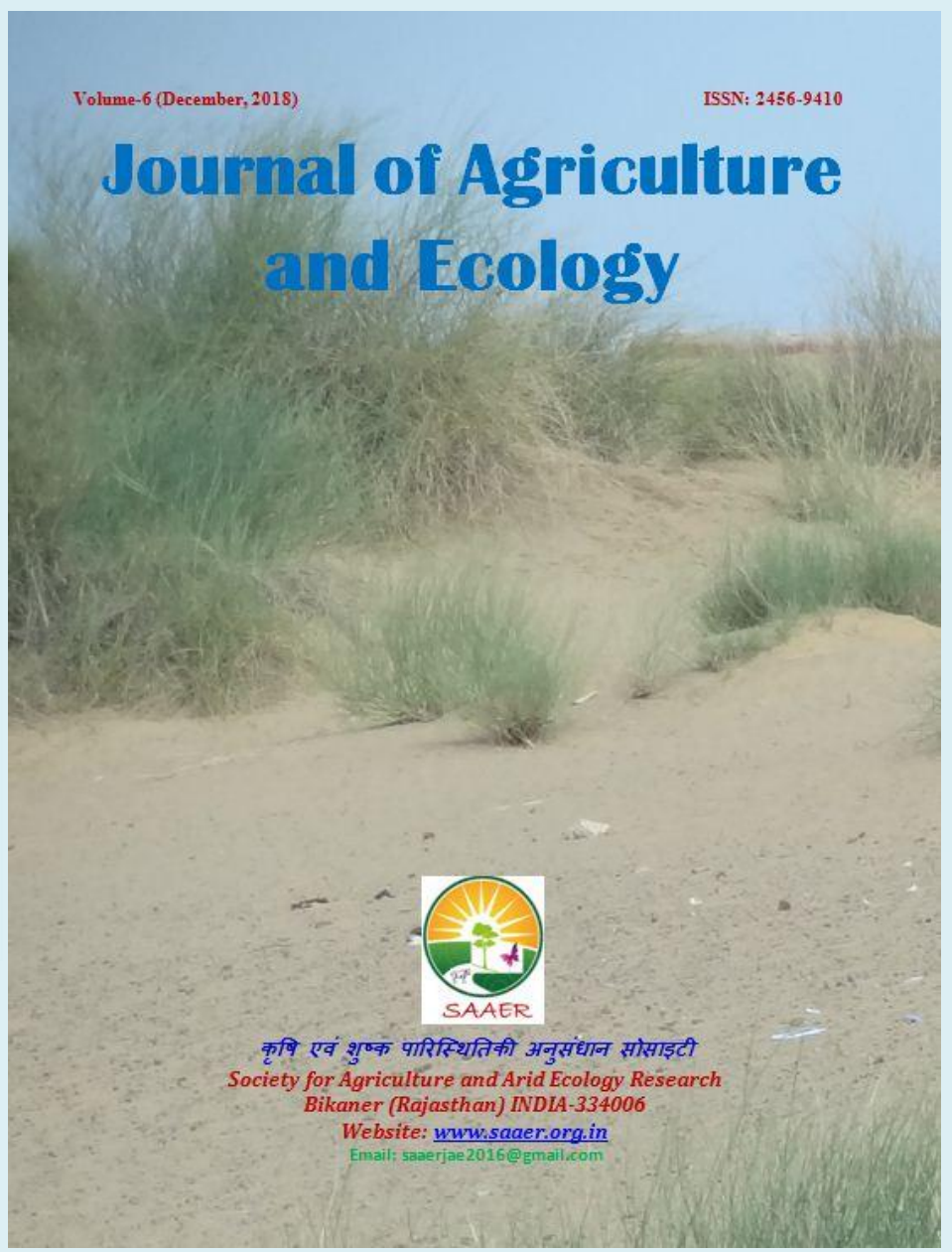




\title{
Standardization of growing media for hardening plantlets of Dendrobium var. Thongchai Gold
}

\author{
VS Sabareeswaran ${ }^{1} \not$, R Swarnapriya ${ }^{2} \&$ M Kannan ${ }^{3}$ \\ ${ }^{I}$ Department of Floriculture and Landscaping, HC \& RI, Tamil Nadu Agriculture University, \\ Coimbatore - 03 \\ ${ }^{2}$ Horticultural Research Station, Pechiparai - 629161 \\ ${ }^{3}$ Adhiparasakthi Horticultural College, Kalavai - 632506 \\ Corresponding author: VS Sabareeswaran, E-mail: sabari29594@gmail.com
}

\begin{tabular}{l}
\hline Article Info \\
\hline Article history \\
Received: 01 August 2018 \\
Accepted: 08 August 2018 \\
Available online: 27 \\
November 2018 \\
\hline
\end{tabular}

Key Words:

Dendrobium, In vitro plantlets, hardening, media, shade net.

\begin{abstract}
An experiment was conducted at Horticultural Research Station, Pechiparai, Tamil Nadu Agricultural University during the year 2017-2018 to standardize the media for hardening the plantlets of Dendrobium var. Thongchai Gold. The in vitro plantlets were hardened with four different growing media and their combinations viz., charcoal, coconut husk, broken pot pieces, thermocol and their combinations as charcoal + coconut husk $(1: 1)$, charcoal + broken pot pieces $(1: 1)$, charcoal + thermocol $(1: 1)$, coconut husk + broken pot pieces $(1: 1)$, coconut husk + thermocol $(1: 1)$, charcoal + coconut husk + broken pot pieces $(1: 1: 1)$ and charcoal + coconut husk + broken pot pieces + thermocol $(1: 1: 1: 1)$. The results revealed that combination of coconut husk and broken pot pieces in 1:1 ratio significantly enhanced the plant height $(9.02 \mathrm{~cm})$ and number of leaves per plantlet (4.61) while the control recorded the plant height of $(7.47 \mathrm{~cm})$ with 3.50 leaves per plant. The leaf length $(6.96 \mathrm{~cm})$, root length $(6.90 \mathrm{~cm})$ and shoot girth $(3.20 \mathrm{~mm})$ were the highest in the treatment combination of coconut husk and broken pot pieces in 1:1 ratio. In the control the leaf length (5.52 $\mathrm{cm})$, root length $(5.30 \mathrm{~cm})$ and shoot girth $(2.20 \mathrm{~mm})$ respectively. The highest survival per cent of 83.49 was recorded in the same treatment where as the survival per cent in the control was 62.55 . Hence it can be concluded that the treatment combination of coconut husk and broken pot pieces in 1:1 ratio was the best medium for hardening the in vitro plantlets of Dendrobium var. Thongchai Gold.
\end{abstract}

\footnotetext{
Copyright (02018 Sabareeswaran et al., This is an open access article published under the terms of the Creative Commons Attribution License, which permits unrestricted use, distribution, and reproduction in any medium, provided the original work is properly cited.

Preferred citation: Sabareeswaran VS, Swarnapriya R \& Kannan M. 2018. Standardization of growing media for hardening plantlets of Dendrobium var. Thongchai Gold. Journal of Agriculture and Ecology, 6: 64-70; http://doi.org/10.53911/JAE.2018.6208.
} 


\section{Introduction}

Orchids are the most beautiful flowers in God's creation and are very unique. They are most pampered plants and occupy top position among all the flowering plants in aestheticity. They are valued for cut flowers and as potted plants. They are known for their longer lasting and bewitchingly beautiful flowers which fetch a very high price in the international market. Orchids exhibit an incredible range of diversity in size, shape and color of their flowers. As a family they stand apart, divided by their mode of growth, formation of flowers and seed production. They are epiphytic, terrestrial, lithophytes, semiaquatic and few are saprophytic. Among cut flowers, orchids occupy 6th position because of their long spikes, many coloured and shaped flowers and long life. Orchid diversity is incredible as they make up the largest family of flowering plants on earth, with about 800 genera, 20,000 different species and at least 200,000 hybrids

Micropropagation of orchids is the most frequently used convenient technique for their perpetuation which is also a major trade in developed countries (Sagawa and Kunisaki, 1982). Large-scale multiplication of orchids, especially rare hybrids and endangered species using tissue culture techniques has helped orchids occupy a position as one of the top ten cut flowers. Orchid propagation by seeds results in the production of heterozygous plants. The success of tissue culture depends on the sustainability of the produced plants under natural conditions. Under laboratory conditions, the plantlets are heterotrophs and so they have to be gradually converted into autotrophs. Pre-hardening and hardening are the processes that make Dendrobium plantlets adaptable to growing environment (Beura 1998). Direct transfer of tissue culture raised plants to field/wild is not possible due to high rate of mortality, as the regenerates in the culture has been cosseted in environment with a very high humidity, varied light and temperature condition and being protected from the attack of microbial and other agents. Direct transfer to sunlight also causes charring of leaves and wilting of the plants (Lavanya et al. 2009). So hardening studies of in vitro derived plantlets in Dendrobium is essential for better survival and successful establishment. Hence, this research work was carried out with the following objective of standardization of the media for hardening plantlets of Dendrobium var. Thongchai Gold.

\section{Materials and Methods}

The present investigation was carried out during the year 2017-2018 at Horticultural Research Station, Pechiparai which is geographically located at an altitude of $76 \mathrm{~m}$ above mean sea level and between $8^{\circ} 26^{\prime}$ North latitude and $77^{\circ} 19^{\prime}$ East longitude. The study was designed under Completely Randomized Design (CRD) with three replications. The rooted plantlets of Dendrobium var. Thongchai Gold varying in height from 2.5 to $3 \mathrm{~cm}$ was procured from an orchid farm in Kanniyakumari District. These were planted in perforated plastic pots filled with different growing media according to treatments specification and placed orchid in trays. The media used for this study were charcoal, coconut husk, broken pot pieces, 
thermocol and combinations of these in various proportions. The pots were kept in $75 \%$ black agro shade net for further observations. The observations such as plant height, number of leaves per plant, leaf length, leaf width, shoot girth, root length, root volume, number of roots per plant and survival percent were recorded after 90 days of planting.

Leaf area was measured with the help of leaf area meter (LICOR-10 model) and expressed in $\mathrm{cm}^{2}$. The total chlorophyll content was assessed by following method suggested by Yoshida et al. (1976) and expressed in $\mathrm{mg} / \mathrm{g}$ on fresh weight basis. The statistical analysis was done by adopting the standard procedures of Panse \& Sukhatme (1985). The critical difference was worked out at five per cent (0.05) probability. The per cent values were transformed to angular (arc-sine) values for analysis. Analysis was carried out with AGRES software package.

\section{Results and Discussion}

The results of study pertaining to influce of growing media were summarized in Table 1 and 2 summarized below. Careful maintenance of plantlets during initial days of transplantation is of utmost importance. During in vitro cultures, plantlets were grown under high humid conditions inside jars. Humidity is much lesser in the outside environment. Therefore, a rapid change in environmental conditions, especially in terms of temperature, humidity, carbon dioxide concentration and irradiance, produces wilting and increases plantlets mortality rate (Posposilova et al. 1999). The quality of the growing medium and nutrient management has a significant influence on growth of floricultural plants (Blanchard \& Runkle 2007). In the present study, among the different treatments, coconut husk and broken pot pieces combination recorded superior performance for plant height $(9.02 \mathrm{~cm})$, number of leaves per plant (4.61), leaf length $(6.96 \mathrm{~cm})$ and shoot girth (3.20) on 90 days after planting which was followed by coconut husk alone for all the above said parameters whereas minimum values have been registered in thermocol. The beneficial effects of charcoal, cocopeat and coconut chunks as growing media for orchids have been emphasised by many earlier workers (Bose \& Bhattacharjee 1980).

Table 1. Effect of different media combination on shoots parameters of Dendrobium plantlets at 90 days after planting

\begin{tabular}{|c|c|c|c|c|c|c|c|}
\hline Treatments & $\begin{array}{l}\text { Plant } \\
\text { height } \\
(\mathrm{cm})\end{array}$ & $\begin{array}{l}\text { Shoot girth } \\
\quad(\mathrm{mm})\end{array}$ & $\begin{array}{c}\text { Number of } \\
\text { leaves per } \\
\text { plant } \\
\text { (Nos.) }\end{array}$ & $\begin{array}{l}\text { Leaf length } \\
\quad(\mathrm{cm})\end{array}$ & $\begin{array}{l}\text { Leaf width } \\
\quad(\mathrm{cm})\end{array}$ & $\begin{array}{c}\text { Leaf area } \\
\left(\mathrm{cm}^{2}\right)\end{array}$ & $\begin{array}{l}\text { Survival } \\
\text { Per cent }\end{array}$ \\
\hline $\mathrm{M}_{1}$ & 7.47 & 2.20 & 3.50 & 5.52 & 1.18 & 21.64 & 62.55 \\
\hline $\mathrm{M}_{2}$ & 8.28 & 2.78 & 4.10 & 6.28 & 1.42 & 26.04 & 73.14 \\
\hline $\mathrm{M}_{3}$ & 7.11 & 2.15 & 3.37 & 5.24 & 1.15 & 19.71 & 49.56 \\
\hline $\mathrm{M}_{4}$ & 6.26 & 1.90 & 3.02 & 4.51 & 1.00 & 14.70 & 69.08 \\
\hline $\mathrm{M}_{5}$ & 7.59 & 2.46 & 3.60 & 5.58 & 1.19 & 25.85 & 57.16 \\
\hline $\mathrm{M}_{6}$ & 7.35 & 2.16 & 3.37 & 5.54 & 1.10 & 22.28 & 48.60 \\
\hline $\mathbf{M}_{7}$ & 7.02 & 2.25 & 3.48 & 5.55 & 1.16 & 19.95 & 38.50 \\
\hline $\mathrm{M}_{8}$ & 9.02 & 3.20 & 4.61 & 6.96 & 1.30 & 30.50 & 83.49 \\
\hline
\end{tabular}




\begin{tabular}{lccccccc}
\multicolumn{1}{c}{$\mathrm{M}_{9}$} & 7.42 & 2.30 & 3.50 & 5.26 & 1.18 & 21.68 & 57.20 \\
$\mathrm{M}_{10}$ & 7.35 & 2.22 & 3.39 & 5.38 & 1.14 & 17.56 & 60.58 \\
$\quad \mathrm{M}_{11}$ & 7.25 & 2.15 & 3.45 & 5.08 & 1.10 & 18.64 & 50.83 \\
\multicolumn{1}{c}{$\mathrm{M}_{12}$} & 7.04 & 2.20 & 3.40 & 5.60 & 1.10 & 18.95 & 49.77 \\
\hline Mean & 7.43 & 2.33 & 3.57 & 5.54 & 1.16 & 21.40 & 58.33 \\
SEd & 0.23 & 0.10 & 0.12 & 0.19 & 0.04 & 0.96 & 1.82 \\
$\mathrm{CD}(\mathrm{P}=0.05)$ & 0.50 & 0.20 & 0.26 & 0.41 & 0.08 & 2.10 & 3.98 \\
\hline
\end{tabular}

$$
\begin{aligned}
& M_{1}-\text { Charcoal (Control) } \\
& M_{2}-\text { Coconut husk } \\
& M_{3}-\text { Broken pot pieces } \\
& M_{4}-\text { Thermocol } \\
& M_{5}-\text { Charcoal + Coconut husk } \\
& M_{6}-\text { Charcoal + Broken pot pieces }
\end{aligned}
$$

$\mathrm{M}_{7} \quad$ - Charcoal + Thermocol

$\mathrm{M}_{8} \quad$ - Coconut husk + Broken pot pieces

$\mathrm{M}_{9}$ - Coconut husk + Thermocol

$\mathrm{M}_{10}$ - Broken pot pieces + Thermocol

$\mathrm{M}_{11}$ - Charcoal + Coconut husk + Broken pot pieces

$\mathrm{M}_{12}$ - Charcoal + Coconut husk + Broken pot pieces + Thermocol

Combination of coconut husk and broken pot pieces in the present study would have constituted a conducive growing media environment, resulting in superior performance with respect to plant height, number of leaves, leaf length, leaf width and shoot girth. Being epiphytic in nature, orchids require physical support for their sustained growth. Coconut husks and chunks serve the same purpose. This was found to be in consonance with the previous work done by Gowda et al. (2005) in Anthurium cv. Lady Jane. The similar trend was observed by Arumugam and Jawaharlal (2004) in Dendrobium orchid cv. Sonia-17. Growth performance in thermocol was very low as it did not have any capacity to absorb the nutrients. In epiphytic orchids such as Dendrobium, roots play a significant role in providing anchorage and also in absorption of water and nutrients through the velamen tissues of roots. The velamen has other functions including amplifying access to mineral rich solution (Benzing \& Friedman, 1982) reducing transpiration, offering substantial mechanical protection (Pridgeon 1986) and exchanging carbon dioxide between the root and atmosphere. Thus, the root parameters in epiphytic orchids are profoundly influenced by the growing medium characteristics (Wang 1995). In the present study, the treatment coconut husk + broken pot pieces have recorded superior performance for most of the root parameters also, similar to their performance for shoots parameters. This may probably be due to optimum water holding capacity, better aeration and drainage in the media, which provide suitable condition for further growth and development.

Media with charcoal + coconut husk in 1:1 ratio recorded superior performance for only two parameters, root volume (2.08 $\mathrm{cm}^{3}$ ) and number of roots per plant (18.2). Superior performance with respect to these root parameters may be attributed to the presence of coconut husk in the media, which might have played a role in improving the physical parameters of the media such as porosity, water retention capacity, drainage etc., and in turn result in improved root growth. The other parameters were the best in the treatment 
combination of coconut husk and broken pot pieces in 1:1 ratio where in the coconut husk is one of the components. Suitability of coconut fibre derived components as growing media for orchids has been reported by many earlier workers (Paul \& Rajeevan 1992). Wang (1995) also observed differential response of Dendrobium and Phalaenopsis plants with respect to root parameters and emphasized that an ideal growing medium for orchids should ensure adequate porosity, drainage and water retention capacity.

The maximum survival percent (83.49) after 90 DAP was recorded in coconut husk and broken pot piece combination and minimum survival percent (38.50 per cent) was recorded by combination of charcoal + thermocol. The results of the present investigation are in partial agreement with that of Sharma (1995) who reported that the media combination comprising of brick, charcoal, tree fern, bark pieces, leaf mould, dry

Table 2. Effect of different media combination on root and bio chemical parameters of Dendrobium plantlets at 90 days after planting

\begin{tabular}{ccccc}
\hline Treatments & $\begin{array}{c}\text { Root length } \\
(\mathrm{cm})\end{array}$ & $\begin{array}{c}\text { Root volume } \\
\left(\mathrm{cm}^{3}\right)\end{array}$ & $\begin{array}{c}\text { Number of roots } \\
\text { per plant (Nos. })\end{array}$ & $\begin{array}{c}\text { Chlorophyll content } \\
(\mathrm{mg} / \mathrm{g})\end{array}$ \\
\hline $\mathrm{M}_{1}$ & 5.30 & 1.00 & 14.2 & 0.424 \\
$\mathrm{M}_{2}$ & 6.25 & 1.20 & 16.5 & 0.947 \\
$\mathrm{M}_{3}$ & 4.89 & 0.92 & 13.4 & 0.529 \\
$\mathrm{M}_{4}$ & 3.62 & 0.72 & 10.3 & 0.645 \\
$\mathrm{M}_{5}$ & 4.83 & 2.08 & 18.2 & 0.895 \\
$\mathrm{M}_{6}$ & 4.50 & 0.90 & 13.2 & 0.802 \\
$\mathrm{M}$ & 5.12 & 0.92 & 14.5 & 0.710 \\
$\mathrm{M}_{8}$ & 6.90 & 1.50 & 16.5 & 1.161 \\
$\mathrm{M}_{9}$ & 5.76 & 1.00 & 14.7 & 0.787 \\
$\mathrm{M}_{10}$ & 4.36 & 0.95 & 14.4 & 0.822 \\
$\mathrm{M}_{11}$ & 4.53 & 1.00 & 11.8 & 0.741 \\
$\mathrm{M}_{12}$ & 5.32 & 1.00 & 14.5 & 0.808 \\
\hline $\mathrm{Mean}$ & 5.12 & 1.10 & 14.35 & 0.7726 \\
$\mathrm{SEd}$ & 0.21 & 0.05 & 0.50 & 0.0276 \\
$\mathrm{CD}(\mathrm{P}=0.05)$ & 0.45 & 0.09 & 1.08 & 0.0602 \\
\hline
\end{tabular}

sphagnum moss in the ratio $(1: 1: 1: 1: 1: 2)$ was considered suitable for maximum survival of Dendrobium and chrysanthemum seedlings.

In the present study, 1:1 of coconut husk + broken pot pieces and coconut husk recorded superior performance for leaf area $\left(30.50 \mathrm{~cm}^{2}\right)$ and total chlorophyll content $(1.161 \mathrm{mg} / \mathrm{g})$. This may be attributed to the improved growth performance Similarly the role of leaves and pseudobulbs of Oncidium in improving the photosynthesis by serving as sinks has been recognized by (Hew and Yong, 1994). Further, the role of pseudobulb as a food storage organ has been emphasized by (Stern et al. 1993). Enzymatic and hormonal mechanism stimulate metabolic process such as sugar mobilization, protein hydrolysis, oxidation, etc., (Puls and Lambeth, 1974) which may lead to increase in root length, shoot length and seedling dry weight and in turn increase the seedling vigour. 


\section{Conclusion}

Considering the results of present investigation, it can be concluded that the treatment combination of coconut husk + broken pot pieces was found to be the best in terms of vegetative parameters viz., highest plant height, more number of leaves per plant, leaf length, shoot girth, root length and survival per cent. It was also observed that the composition of growing media had a great influence on growth parameters. So, ex-vitro hardening with growing media with the combination of coconut husk and broken pot pieces in 1:1 ratio was the best medium for hardening the in vitro plantlets of Dendrobium var. Thongchai Gold. So the charcoal media which is being used can be successfully replaced with the combination of coconut husk + broken pot pieces in 1:1 ratio.

\section{References}

Arumugam T \& Jawaharlal M. 2004. Effect of shade levels and growing media on growth and yield of Dendrobium orchid cultivar Sonia-17. Journal of Ornamental Horticulture, 7(1): 107110.

Benzing DH, Ot, DW \& Friedman WE. 1982. Roots of Sobralia macrantha (Orchidaceae): structure and function of the velamen-exodermis complex. American Journal of Botany, 608-614.

Beura S. 1998. In vitro multiplication, Agrobacterium mediated transformation and post harvest handling of spikes in Gladiolus. Ph. D. Thesis, G.B Pant University of Agriculture Technology, Pantnagar, $220 \mathrm{p}$.
Blanchard MG \& Runkle ES. 2007. Container opacity and media components influence rooting of potted Phalaenopsis and Doritaenopsis orchids. In International Workshop on Ornamental Plants 788 (pp. 115-120).

Bose TT \& Bhattacharjee SK. 1980. Orchids of India. Naya Prokash, India.

Gowda JVN, Gowda MC \& Gowda APM. 2005. Influence of different growing media on vegetative growth of anthurium cv. Lady Jane. Crop research, 30(2): 283.

Hew CS \& Yong JWH. 1994. Growth and photosynthesis of Oncidium "Goldiana." Journal of Horticultural Science, 69(5): 809-819.

Lavanya M, Venkateshwarlu B \& Devi BP. 2009. Acclimatization of neem microshoots adaptable to semi-sterile conditions. Indian Journal of Biotechnology, 8: 218-222.

Panse VG \& Sukhatme PV. 1985. Statistical methods for agricultural research. ICAR, New Delhi.

Paul CA \& Rajeevan PK. 1992. Influence of media on growth parameters in Dendrobium. Journal of Orchid Soceity, 6(1-2): 125-130.

Posposilova J, Ticha I, Kadlecek P, Haisel D \& Plzakova S. 1999. Acclimatization of micropropagated plants to ex vitro conditions. Biologia Plantarum, 42(4): 481-497.

Pridgeon AM. 1986. Anatomical adaptations in Orchidaceae. Lindleyana, 1: 90-101. 
Puls EE \& Lambeth VN. 1974. Chemical stimulation of germination rate in aged tomato seeds. Journal of the American Society for Horticultural Science.

Sagawa Y \& Kunisaki JT. 1982. Clonal propagation of orchids by tissue culture. Fujiwara A. (ed.), 683-684.

Sharma J \& Chauhan YS. 1995. Establishment of Dendrobium raised seedlings of Dendrobium and Paphiopedilum. Journal of the Orchid Society of India, 9: 37-41.
Stern WL, Morris MW, Judd WS, Pridgeon AM \& Dressler RL. 1993. Comparative vegetative anatomy and systematics of Spiranthoideae (Orchidaceae). Botanica Journal of Linnean Society, 113: 161-197.

Wang YT. 1995. Medium and fertilization affect performance of potted Dendrobium and Phalaenopsis. HortTechnology, 5(3): 234-237.

Yoshida S, Cock J \& Forno DA. 1976. Laboratory manual for physiological studies of rice. Int. Rice Res. Institute. 